\title{
Drift algal blooms enhance nitrogen recycling and nitrous oxide emissions
}

\author{
PERran COOK ${ }^{1}$, Chris GREENING ${ }^{2}$, GUY SHELley ${ }^{2}$, \\ ADAM KESSLER $^{3}$, WEI WEN WONG ${ }^{1}$ \\ ${ }^{1}$ Water, Studies, School of Chemistry, Monash University, \\ perran.cook@monash.edu \\ ${ }^{2}$ School Microbiology, Monash University. \\ chris.greening@monash.edu \\ ${ }^{3}$ School of Earth Atmosphere and Environment, Monash \\ University, adam.kessler@monash.edu
}

Nitrogen is commonly the nutrient limiting production in coastal waters. Excessive nitrogen inputs to coastal waters often lead to eutrophication and blooms of macroalgae. Bioavaialable nitrogen can be removed though the processes of denitrification and anammox which have the potential to reduce the impacts of eutrophication. These processes however compete with nitrogen recycling processes (dissimilatory nitrate reduction to ammonium, DNRA) and the production of the greenhouse gas $\mathrm{N}_{2} \mathrm{O}$. Here we present a case study of the effect of macroalgal blooms (Stenogramma interruptum) on the nitrogen cycle in permeable sediments impacted by high nitrogen loading from a seawage treatment plant and submarine groundwater discharge in Port Phillip Bay, Melbourne Australia. We measured denitrification, DNRA anammox and nitrous oxide production as well as nitrogen cycling gene expression and microbial community structure in permeable sediments with different amounts of added macroalgal material and nitrate pre-exposure $\left(\sim 700 \mu \mathrm{mol} \mathrm{L}^{-1}\right.$ for 72 hours). We found that the presence of macro-algae dramatically increased DNRA and nitrous oxide production with no pre-exposure to nitrate. With nitrate preexposure, DNRA and nitrous oxide production dropped dramatically and denitrification increased coincident with an increase in the NarG (nitrate reduction), NirS (nitrite reduction) and NosZ $\left(\mathrm{N}_{2} \mathrm{O}\right.$ reduction to $\left.\mathrm{N}_{2}\right)$ genes and a decrease in the NrfA (DNRA) gene. This coincided with a dramatic decrease in the abundance of firmicutes with nitrate pre-exposure. Pre-exposure to nitrate led to an increase in anammox coincident with an increase in the population of planctomycetes. These findings highlight the importance of microbial community structure and succession in controlling environmental responses to nitrogen inputs which can be highly temporally variable. 